\title{
Communication
}

\section{Features of the Largest Earthquake Seismic Cycles in the Western Part of the Aleutian Subduction Zone}

\author{
Leopold I. Lobkovsky ${ }^{1,2, *}$, Irina S. Vladimirova ${ }^{2,3}$, , Yurii V. Gabsatarov ${ }^{2,3}$ and Dmitry A. Alekseev and, $^{1, *}$ \\ 1 P.P. Shirshov Institute of Oceanology, Russian Academy of Sciences, 117997 Moscow, Russia \\ 2 Moscow Institute of Physics and Technology (MIPT), 141701 Dolgoprudny, Russia; vladis@gsras.ru (I.S.V.); \\ yuryg@gsras.ru (Y.V.G.) \\ 3 Geophysical Survey, Russian Academy of Sciences, 249035 Obninsk, Russia \\ 4 Schmidt Institute of Physics of the Earth, Russian Academy of Sciences, 123242 Moscow, Russia \\ * Correspondence: llobkovsky@ocean.ru (L.I.L.); alekseev.da@mipt.ru (D.A.A.)
}

check for

updates

Citation: Lobkovsky, L.I.;

Vladimirova, I.S.; Gabsatarov, Y.V.; Alekseev, D.A. Features of the Largest Earthquake Seismic Cycles in the Western Part of the Aleutian Subduction Zone. Geosciences 2022, 12, 107. https://doi.org/10.3390/ geosciences 12030107

Academic Editors: Rosa Nappi and Jesus Martinez-Frias

Received: 16 October 2021

Accepted: 21 February 2022

Published: 24 February 2022

Publisher's Note: MDPI stays neutral with regard to jurisdictional claims in published maps and institutional affiliations.

Copyright: (c) 2022 by the authors. Licensee MDPI, Basel, Switzerland. This article is an open access article distributed under the terms and conditions of the Creative Commons Attribution (CC BY) license (https:/ / creativecommons.org/licenses/by/ $4.0 /)$.

\begin{abstract}
We discussed the peculiarities of the seismic cycle in Aleutian subduction zone, characterized by an oblique subduction setting. It was shown that the orientation of the plate convergence vector relative to the subduction zone axis can have a significant impact on the preparation and occurrence of the largest earthquakes in subduction zones. In particular, from the analysis of the seismic activity occurring in the western part of the Aleutian island arc, it was found that the seismic cycles here are shorter than in the eastern part of the arc. It was revealed that the strongest earthquakes, repeating in the same areas of the western part of the Aleutian subduction zone, differ both in magnitude and length of the fault zone. Taking into account the oblique subduction setting, we proposed the keyboard model of the largest megathrust earthquakes generation as a mechanism potentially capable of explaining the reduction in the seismic cycle duration and noticeable differences in the spatial extent and localization of the fault zones of events with similar magnitudes occurring in the same segment of the western half of the Aleutian subduction zone.
\end{abstract}

Keywords: largest earthquakes; oblique subduction; seismic cycles; Aleutian subduction zone; geodynamics; stress accumulation

\section{Introduction}

Studying seismic process features is of great importance for solving urgent problems of geodynamics and geophysics, particularly large-magnitude earthquake forecasting. Establishing parameters of seismic cycles associated with megathrust earthquakes will significantly improve seismic hazard assessment and provide new data for solving the fundamental problem of earthquake prediction. The average recurrence periods of the large-magnitude earthquakes are on the order of 100-1000 years at active plate boundaries and 1000-10,000 years in their stable inner regions [1]. Since seismic activity is controlled by nearly stationary processes, such as plates' motion, the seismic regime, in particular the seismogenic zone, is also expected to display stationary behavior. However, in reality, due to the effect of various factors, the seismic process may exhibit significant deviations from the stationary pattern. For example, the fluid migration in the Earth's crust can lead to a local decrease in the effective strength of the lithosphere, contributing to the shortening of the time period until the next catastrophic event. In addition, the occurrence of a largemagnitude earthquake itself has a direct impact on the stress-strain state of the neighboring regions of the seismogenic zone, thereby shortening or prolonging the duration of the seismic cycle.

An example of such temporal variability of the seismic process is the increase in seismogenic activity of the Aleutian subduction zone in the middle of the 20th century. During the period from 1938 to 1965, a series of megathrust earthquakes occurred in the Aleutian island arc, with fault zones nearly covering the entire frontal part of the 
Aleutian arc. The western half of the Aleutian arc is of particular interest, since the largest earthquakes with a magnitude of $\sim 8$ occur here more often than in the eastern part of the arc $[2,3]$. The most pronounced difference between these segments is a change in the direction of subduction from nearly orthogonal to the trench (in the eastern part of the zone) to nearly tangential to it (in its western part).

Globally, oblique convergence is much more common than normal subduction. The tangential component plate convergence rate is to some extent identified in different segments of almost all subduction zones of the globe. In addition, the angle of plate convergence within particular subduction zone, as a rule, does not remain constant.

With oblique subduction, the lithospheric plates experience both frontal and lateral interaction. Non-zero tangential components of the plate convergence vector cause the shear stresses subparallel to the plates' boundary to arise. In this case, most of the lateral displacement is transferred to the overhanging edge of the continental plate, which leads to the formation of strike-slip faults oriented both sub-parallel and sub-perpendicular to the subduction axis [4-7].

In general, the subduction zone dynamics are determined not only by the motion of converging plates. The margins of converging lithospheric plates commonly accommodate various-scale discontinuities, such as flower structures, en-echelon faults, transform faults, etc. As a result, a fairly complex displacement and deformation pattern is formed. For example, the rupture of the contact plane between the overhanging and subducting plates during the catastrophic earthquakes can trigger the secondary rupture of the subvertical faults crossing the edge of the overhanging plate [8].

Island arcs are subdivided into segments by numerous faults, with strike being close to orthogonal to the arc [9-12]. The extent of manifestation of these faults in the morphology of the overhanging edge of the continental plate varies from weak to significant, when faults are clearly seen in bathymetry, forming deep straits or submarine canyons. Among the examples of such structures are the Kruzenshtern, Bussol, and Frisa straits in the Kuril Islands, as well as the Adak canyon in the central part of the Aleutian Islands. The transverse segmentation of island arcs is confirmed by the fact that the fault zones of most of the large-magnitude earthquakes cover relatively small areas of the seismic focal zone [13-15].

The existence of active faults within the overhanging edge of the continental plate in combination with oblique subduction of the oceanic plate can have a noticeable effect on the processes of preparation and triggering of the largest earthquakes in subduction regions. The distinctive features of earthquakes that occur in oblique subduction zones include, for example, the formation of extremely large fault zones, with length reaching $1200 \mathrm{~km}$. The most prominent examples of events of that kind are the 1957 M8.6 Aleutian earthquake and the 2004 M9.1 Sumatra-Andaman earthquake.

Based on retrospective analysis of the spatio-temporal distribution of the fault zones associated with the largest earthquakes in the Aleutian subduction zone, we revealed a distinctive feature of the seismic process in the western part of the Aleutian subduction zone, which is the seismic cycle shortening, compared to the eastern part of the island arc. The aim of this study was to identify possible causes behind the reduction in the seismic cycle duration in the western part of the Aleutian subduction zone. We proposed a possible mechanism which can explain the more frequent generation of the megathrust earthquakes under oblique subduction setting.

\section{Seismotectonic Setting in Western Segment of the Aleutian Islands}

The Aleutian island arc is one of the most seismically and tectonically active regions at the Pacific margin. Due to the notable curvature of the arc, the direction of the Pacific and North American lithospheric plates' convergence changes throughout the arc from almost normal to the trench in the eastern part of the subduction zone to subparallel in its western part, near the junction of the Aleutian and Kuril-Kamchatka island arcs. As the tangential component of subduction velocity increases in the westward direction, the compression setting gradually changes to nearly pure right lateral strike-slip, which is accompanied by 
changes in the seismic and volcanic activity manifestations along the arc. The subduction rate does not remain constant either; being around $62 \mathrm{~mm} / \mathrm{yr}$ in the south of the Alaska Peninsula, it increases to $\sim 72 \mathrm{~mm} / \mathrm{yr}$ within the central part of the Aleutian Islands and reaches $\sim 76 \mathrm{~mm} / \mathrm{yr}$ at the western flank of the arc [16,17].

Segmentation of the Alaska-Aleutian subduction zone is discussed in multiple studies based on seismological, geological, space geodesy, and tsunami data [3,15,18,19]. Part of the segments of the subduction interface were considered to be locked while the others were assumed to be creeping. Some authors claimed these creeping areas, which formed long-persistent seismic gaps, as aseismic, but modern studies show that these areas had been ruptured earlier $[20,21]$. The exact determination of the recurrence periods of the megathrust earthquakes in the Aleutian island arc is difficult due to the lack of systematic paleoseismic observations and the sparse population in the region. Statistical seismological studies provide estimates of the duration of the seismic cycle for different segments of the Alaska-Aleutian and for the entire subduction zone [3,22,23]. The existing estimates of the seismic cycle duration are 34-470 years for different segments of the island arc, or 191 year on average for the entire Aleutian-Alaska region. Using data from Table 1, we estimate the average duration of the seismic cycle in the western part of the Alaska-Aleutian island arc at $\sim 40$ years (excluding the Komandor segment), which is significantly less than in the eastern part, which is $\sim 82$ years (excluding the Prince William Sound segment).

Table 1. Largest megathrust earthquakes in the Komandor-Aleutian subduction zone.

\begin{tabular}{|c|c|c|c|c|c|c|c|c|}
\hline \multicolumn{2}{|c|}{ Region } & Date & Latitude & Longitude & Depth & $\mathbf{M}_{\mathbf{w}}$ & Rupture & Source \\
\hline \multirow{7}{*}{ 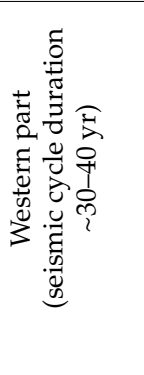 } & $\begin{array}{l}\text { Komandor } \\
\text { Islands }\end{array}$ & 30 Jan 1917 & $55.20^{\circ} \mathrm{N}$ & $164.5^{\circ} \mathrm{E}$ & shallow & 8.0 & no data & {$[24,25]$} \\
\hline & \multirow{3}{*}{ Rat Islands } & 4 Feb 1965 & $51.30^{\circ} \mathrm{N}$ & $178.60^{\circ} \mathrm{E}$ & 36 & 8.7 & $400-600$ & {$[3,25,26]$} \\
\hline & & 30 Jan 1981 & $51.74^{\circ} \mathrm{N}$ & $176.27^{\circ} \mathrm{E}$ & 33 & 7.0 & no data & {$[25,27]$} \\
\hline & & 17 Nov 2003 & $51.15^{\circ} \mathrm{N}$ & $178.65^{\circ} \mathrm{E}$ & 33 & 7.7 & 100 & {$[26,28]$} \\
\hline & \multirow{3}{*}{$\begin{array}{l}\text { Andreanof } \\
\text { Islands }\end{array}$} & 9 Mar 1957 & $51.30^{\circ} \mathrm{N}$ & $175.80^{\circ} \mathrm{W}$ & 33 & 8.6 & $850-1200$ & {$[25,26,29]$} \\
\hline & & 7 May 1986 & $51.50^{\circ} \mathrm{N}$ & $174.80^{\circ} \mathrm{W}$ & 19 & 8.0 & 140 & {$[2,30]$} \\
\hline & & 10 Jun 1996 & $51.56^{\circ} \mathrm{N}$ & $177.63^{\circ} \mathrm{W}$ & 33 & 7.9 & 100 & {$[26,30]$} \\
\hline \multirow{4}{*}{ 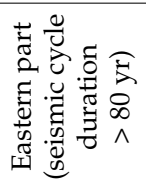 } & \multirow{3}{*}{$\begin{array}{c}\text { Alaska } \\
\text { Peninsula }\end{array}$} & 10 Nov 1938 & $55.50^{\circ} \mathrm{N}$ & $158.00^{\circ} \mathrm{W}$ & 25 & 8.3 & 300 & {$[3,25,26]$} \\
\hline & & 1 Apr 1946 & $52.80^{\circ} \mathrm{N}$ & $162.50^{\circ} \mathrm{W}$ & 50 & 8.6 & 200 & {$[25,31]$} \\
\hline & & 29 Jul 2021 & $55.36^{\circ} \mathrm{N}$ & $157.89^{\circ} \mathrm{W}$ & 35 & 8.2 & $175-200$ & {$[28,32]$} \\
\hline & Alaska & 28 Mar 1964 & $61.10^{\circ} \mathrm{N}$ & $147.60^{\circ} \mathrm{W}$ & 23 & 9.3 & $650-800$ & {$[3,25,26]$} \\
\hline
\end{tabular}

Dimensions of the fault zones associated with the megathrust earthquakes are known from geology - their boundaries are usually determined by the magnitude and structural inhomogeneities at the edge of the overriding plate. The recurrence periods of the megathrust earthquakes within the same focus are mainly determined by the size of the fault zone and the rate of elastic stresses accumulation [30]. The western and eastern parts of the Aleutian island arc have noticeable morphological differences, which can influence the processes of preparation and occurrence of megathrust earthquakes. In the western interval $\left(170^{\circ} \mathrm{W}-164.5^{\circ} \mathrm{E}\right)$, the frontal part of the island arc is divided into blocks by a series of large canyons. These canyons are of tectonic rather than erosive origin [33-35], which means that they can play a significant role in seismogenesis and affect the parameters of the fault zones of megathrust earthquakes occurring here. In the eastern part $\left(170^{\circ}-148^{\circ} \mathrm{W}\right)$ of the island arc, there is a single large (Adak) canyon. A distinctive feature of the eastern part is the presence of groups of small islands predominantly oriented perpendicular to the island arc. Presumably, this structural feature may also reflect the segmentation of the eastern part of the Aleutian island arc. In addition, the eastern and western parts of the Aleutian island arc were found to have different intensity of volcanism, different structure of the western 
and eastern parts of the Bering Plate, and differences in the seismicity manifestation at intermediate depths [30].

Analysis of regional earthquake catalog provided by USGS [28] (data from 1 January 1900 to 1 October 2022, M $\geq 4$.5) favors the high seismogenic potential of the KomandorAleutian subduction zone (Figure 1a). Due to the curvature of the island arc and the corresponding change in the deformation regime, noticeable differences arise in the spatial distribution of earthquake foci along the subduction zone. The eastern part of the subduction zone is characterized by a wider seismicity belt and the presence of the intermediatedepth earthquakes (up to $300 \mathrm{~km}$ deep). In the western part of the subduction zone, there is a noticeable narrowing of the seismicity belt and an almost complete absence of earthquakes with a source depth of more than $35 \mathrm{~km}$. Another difference came from the analysis of the time distribution of regional seismic energy release performed on the basis of ISC-GEM catalog (data from 1 January 1904 to 31 December 2017, Mw $\geq 5.5$ ) [25]. The western part of the subduction zone is characterized by more frequent single megathrust earthquakes, while the eastern part has different pattern characterized by the release of much more seismic energy during a series of earthquakes (Figure 2). Several strong earthquakes $(M>8)$ that occurred within the Aleutian subduction zone are among the strongest seismic events for the entire period of instrumental observations. During the period from 1938 to 1965, the fault zones of these earthquakes filled almost the entire area of the Aleutian island arc and Alaska [23] (Figure 1b). The exception was the Komandor Islands segment, located at the western end of the Aleutian zone. The last megathrust earthquake $(\mathrm{Mw}=8.1)$ in this segment occurred in 1917 (Table 1) and affected only western margin of the Komandor segment [24,36].

(a)

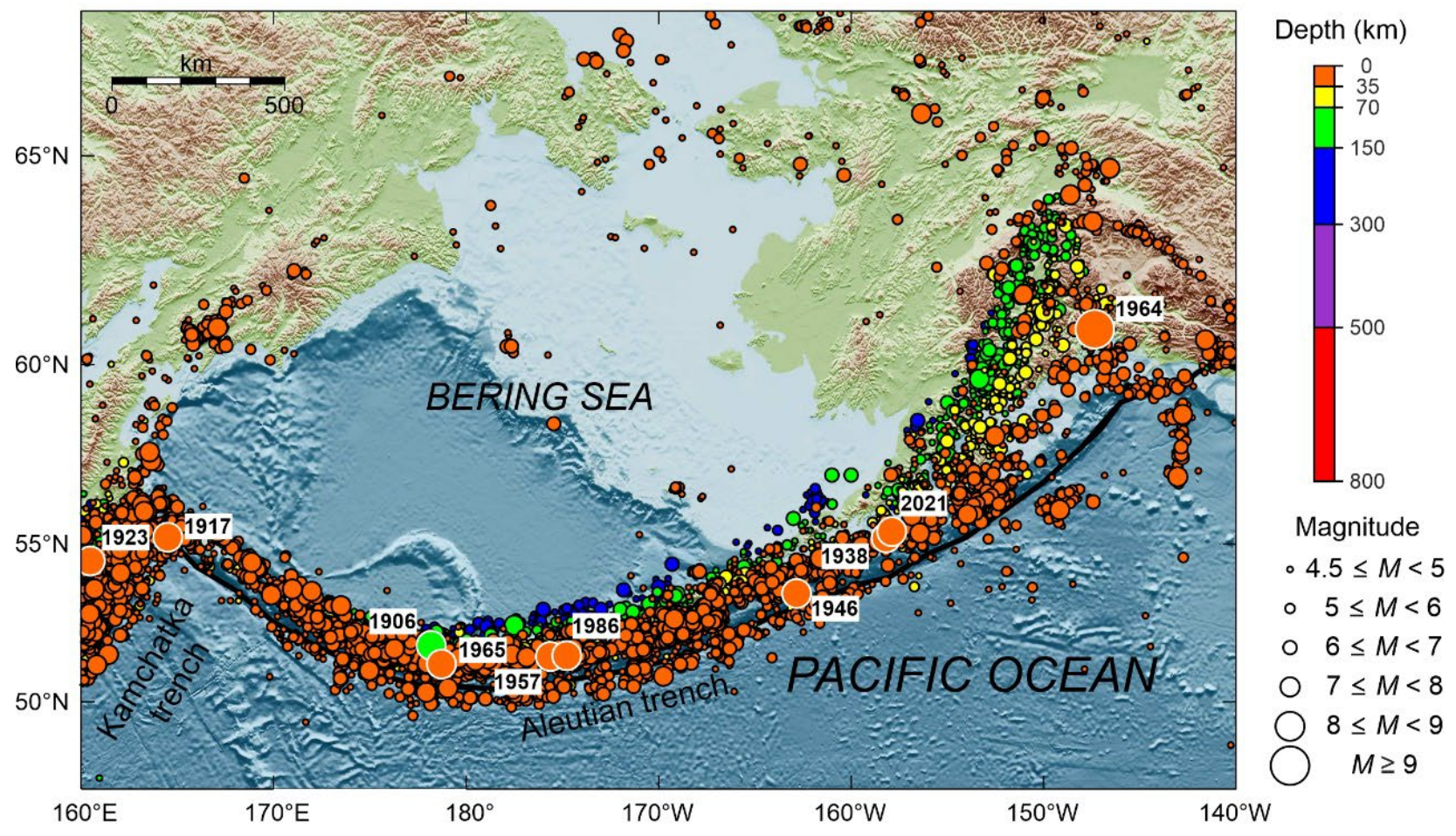

Figure 1. Cont. 
(b)

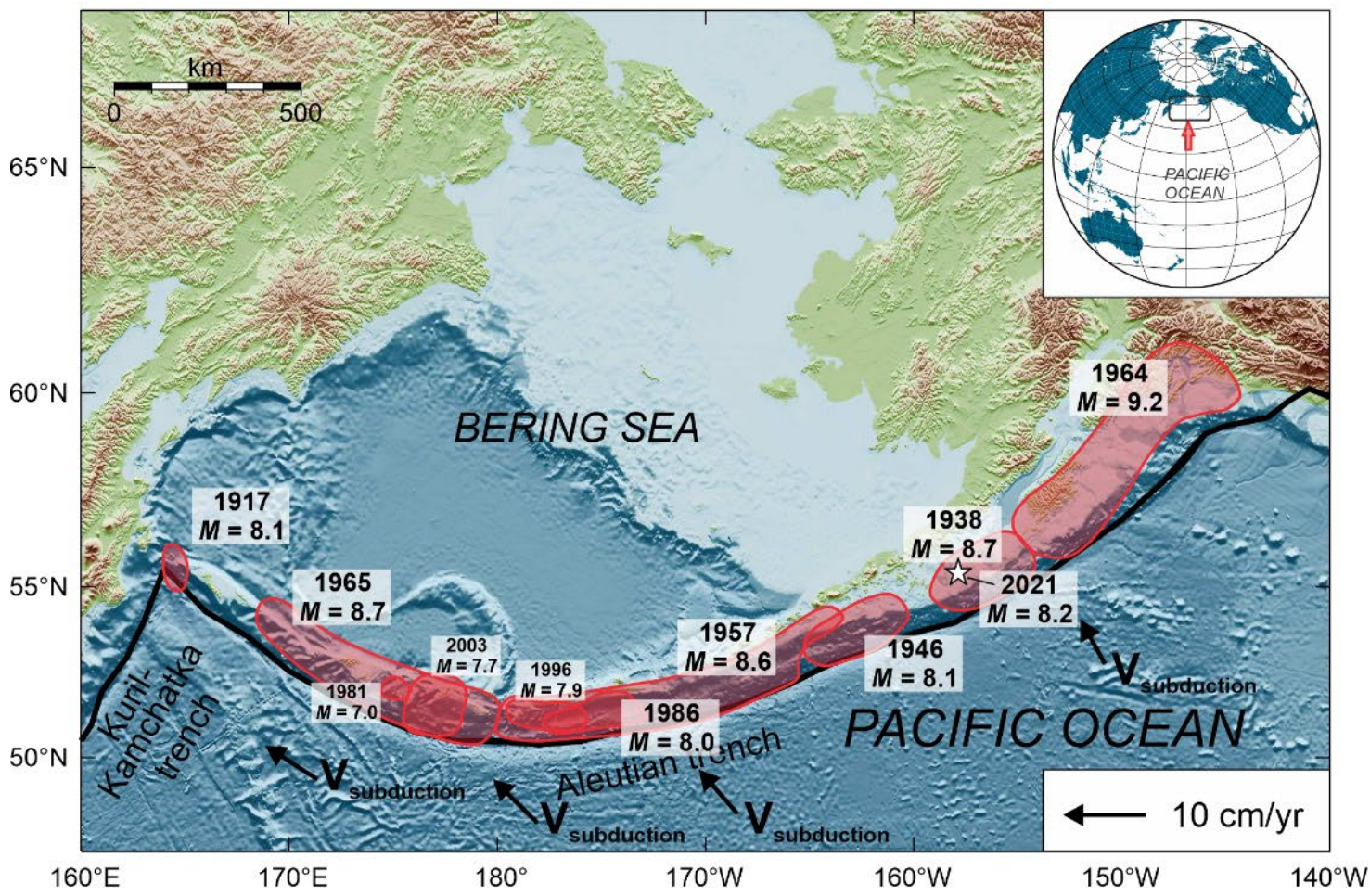

Figure 1. (a) Regional seismicity map based on USGS catalog data $(M>4.5)$ [28]. The largest regional earthquakes $(M \geq 8)$ are denoted by white circles; (b) location of fault zones of the megathrust earthquakes in Alaska and the Aleutian island arc [29,36-38]. 1-subduction rates relative to the North American lithospheric plate (arrow scale is $10 \mathrm{~cm} / \mathrm{yr}$ ).

A retrospective analysis of the spatio-temporal distribution of the fault zones of megathrust earthquakes (Figure $1 \mathrm{~b}$ and Table 1 ) allowed us to identify the main features of the seismic process in the Aleutian subduction zone. Our analysis showed that the features of the seismic cycle in the western half of the Aleutian island arc are of great interest.

In the Rat Islands segment, an M8.7 earthquake occurred on 2 April 1965, with the length of the fault zone exceeding $600 \mathrm{~km}$. Subsequent redistribution of stresses in the fault zone later led to the occurrence of an M7.5 event on 30 March 1975 at the marginal oceanic ridge. The eastern part of the fault zone of the 1965 event was ruptured again in 1981 and 2003 during the M7.0 and M7.7 events, respectively. Presumably, the previous time the entire focal area of the 1965 earthquake was ruptured between 1880 and 1907 during a series of M7-8 events [23,39].

Immediately to the east of the 1965 Rat Islands earthquake, in the Andreanof Islands segment, the fault zone of the M8.6 1957 Great Aleutian earthquake is located. The total length of the source, estimated from the size of the aftershock spatial distribution, was $1200 \mathrm{~km}$ [29]. On 7 May 1986, an earthquake with Mw 8 occurred in the same segment of the island arc. The 1986 event is the most prominent because it took place only 29 years after the previous largest earthquake $(1957, \mathrm{Mw}=8.6)$ in the central segment of the Aleutian island arc. Although earlier, based on the rate of elastic stress accumulation in the Andreanof segment of the Aleutian island arc, it was proposed that the accumulation time required for the seismogenic potential to build up and cause an event of such magnitude would be about 60-90 years [3]. Until the 1986 earthquake, the seismic potential of the 1957 focal zone was considered extremely low over the next several decades. The 1986 event took place at the western flank of the 1957 earthquake, covering only $20 \%$ of its fault zone. The epicenters of the main shocks of the aforementioned earthquakes fall within $1^{\circ}$ area both in latitude and longitude. In 1996 another large earthquake with $\mathrm{M}=7.9$ occurred 
near Adak Island. Its fault zone was also located at the western end of the 1957 fault zone, partially overlapping the fault zone of the 1986 earthquake. Presumably, in 1902-1903, a series of events with magnitudes ranging from 7.4 to 7.9 occurred in the same segment of the island arc [39].

(a)

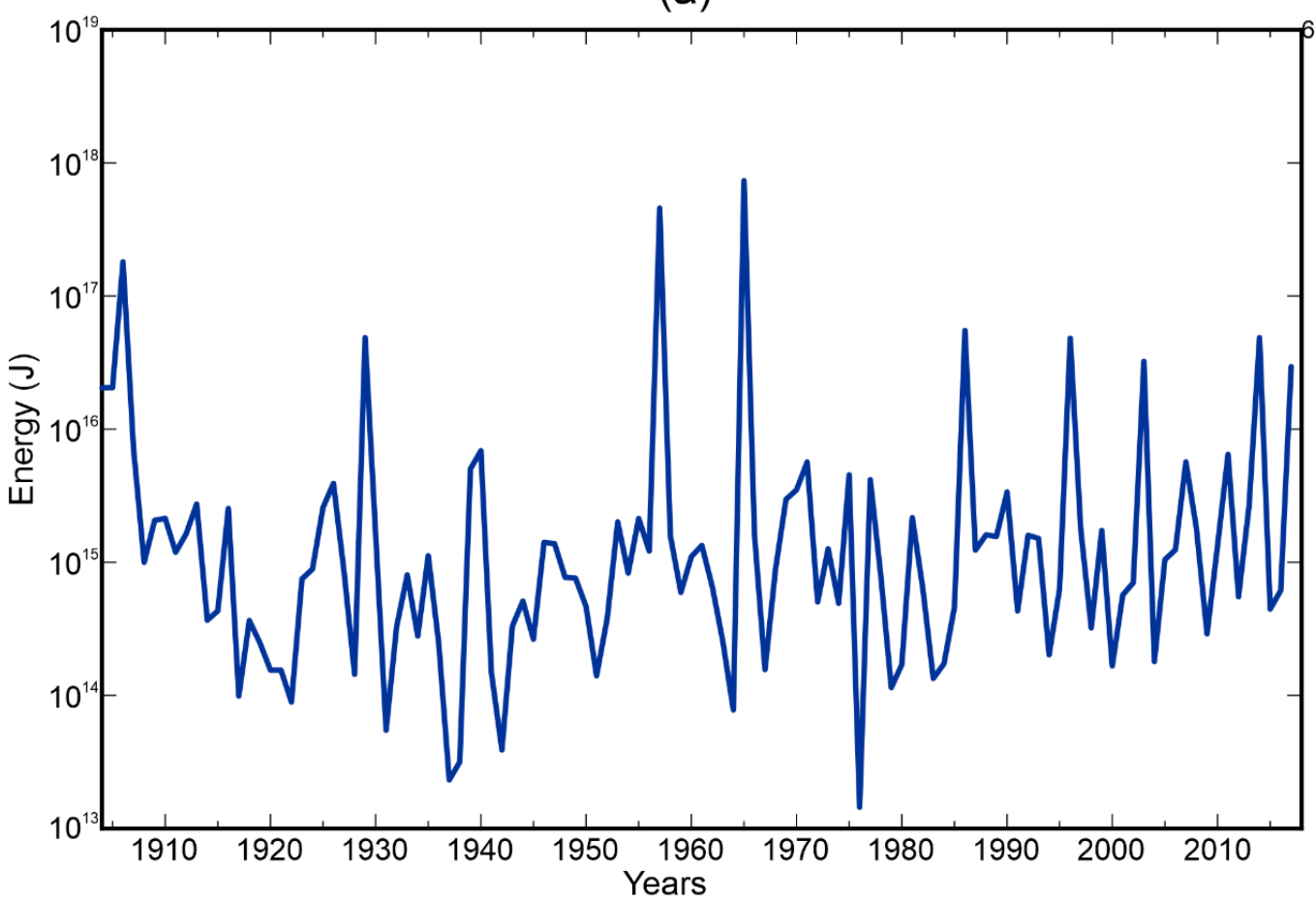

(b)

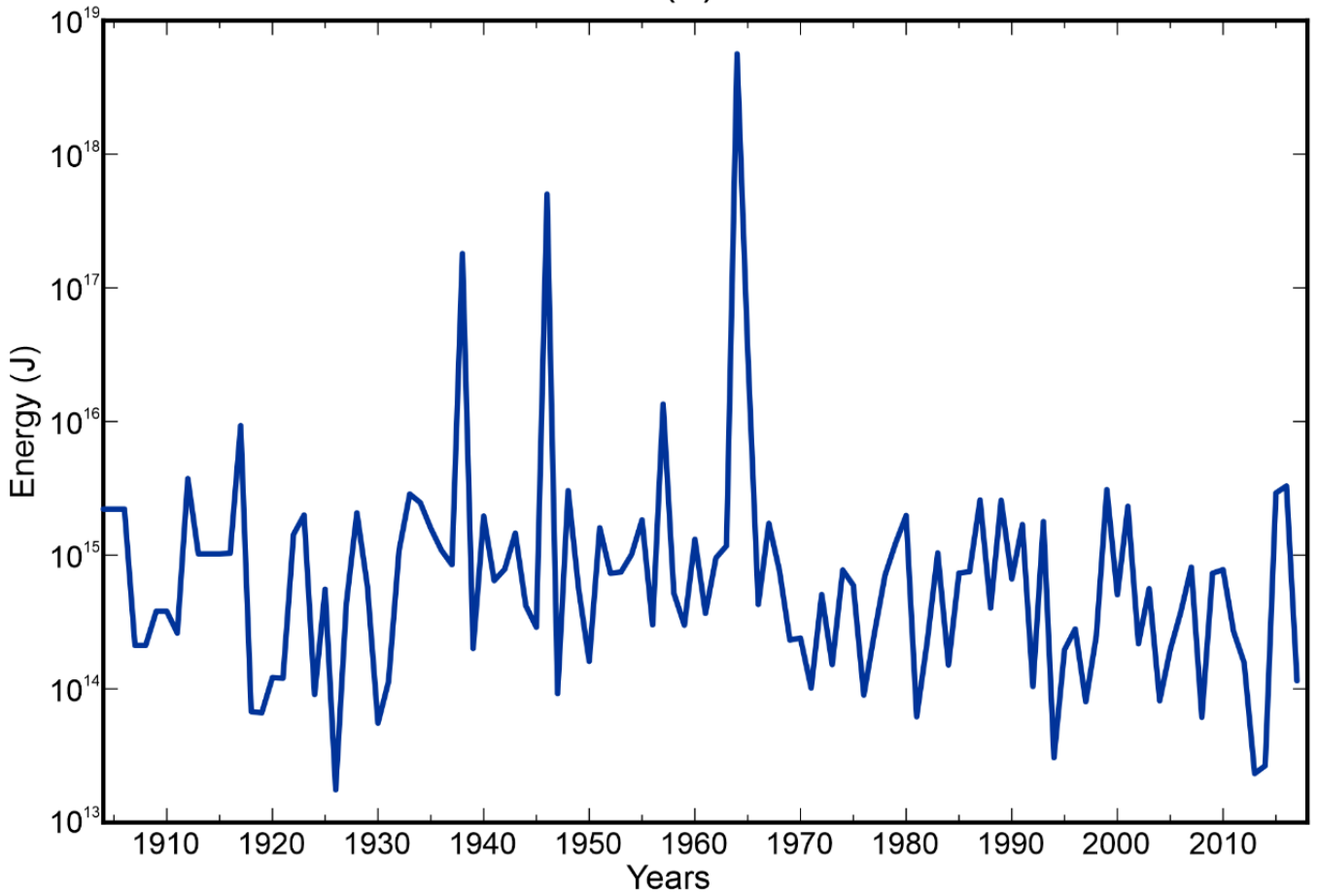

Figure 2. Time distribution of seismic energy release for (a) the western part and (b) the eastern part of the subduction zone. 
The long Alaska Peninsula segment partially ruptured in 1938 during an M8.3 earthquake with $300-\mathrm{km}$-long fault zone that occurred southwest of Kodiak Island. Another significant event in this segment took place on 1 April 1946 at the eastern end of the focal zone of the 1957 earthquake, where the subduction direction is changing from oblique to normal. The magnitude of the earthquake was estimated at 8.6 [31], and the fault length along the strike did not exceed $200 \mathrm{~km}$. The fault zones of 1938 and 1946 earthquakes ruptured different parts of the large subduction zone segment and did not overlap, forming a long-lasting Shumagin gap which was partially broken only in 2020 by the M7.8 Simeonof earthquake on 22 July. The length of the Simeonof earthquake fault zone was about $180 \mathrm{~km}$ [40], which only partially filled the Shumagin gap. A year later, on 29 July 2021, the fault zone of the 1938 earthquake was partially ruptured by the M8.2 Chignik earthquake having $175 \mathrm{~km}$-long fault zone [32]. Historical documents indicate that great earthquakes ruptured at least a 500-km-long segment of the plate boundary near the Alaska Peninsula in 1788 and 1847 [37]. The Alaska Peninsula segment is characterized by rather small lengths of fault zones of megathrust earthquakes and long seismic cycles exceeding 80 years (Table 1 ).

In the Alaska segment the largest (M9.2) earthquake along the Komandor-AlaskaAleutian subduction zone occurred on 28 March 1964. The fault zone of the 1964 earthquake was up to $800 \mathrm{~km}$ long and ruptured the whole segment. Recurrence interval of such devastating megathrust earthquakes has been estimated at about 400-1000 years [2].

As noted in $[12,30]$, the frontal part of the Aleutian island arc has a blockwise structure. The blocks are separated from each other by faults and canyons crossing the lithospheric plate margin in the direction perpendicular to the deep-sea trench, and their characteristic lengths vary from several tens to a few hundreds of kilometers. Fault zones and submarine canyons bounding the blocks also serve as the boundaries of the fault zones of the megathrust earthquakes. At the same time, the fault zones of megathrust earthquakes may involve several blocks at once. For example, the length of fault zones of the M8.6 1957 and M8.7 1965 earthquakes were estimated as 1200 and $650 \mathrm{~km}$, respectively, which indicates a consistent displacement of several large blocks at once [7]. According to [34], tangential tensile stresses arise in the Aleutian island arc as a result of non-orthogonal subduction. Based on the satellite geodetic data analysis, it was found that the blocks of the Aleutian arc move along the oceanic trench in the westward direction. Besides, an increase in the shear component of the convergence vector is accompanied by increase in the rates of tangential motion of blocks, varying from 3.1 to 9.6 and $31.4 \mathrm{~mm} /$ year in the eastern, central, and the western part of the arc, respectively [41]. Thus, the main features of the dynamics of the western segment of the Aleutian island arc are the blockwise structure of the continental margin, the presence of a significant tangential component of the blocks' motion, and a significant shortening of seismic cycles.

\section{Models of Subduction Zone Dynamics}

\subsection{Asperity Model}

The study of the spatial and temporal patterns of the earthquake fault zones in subduction regions led to the creation of a number of geomechanical models describing the generation of the large seismic events. One of the most widely used models is the so-called "asperity" model [42], which explains the difference in the characteristic source sizes and recurrence periods of catastrophic earthquakes associated with different subduction zones. The proposed model, however, does not consider the long-term transient postseismic processes following large-magnitude events. These processes can have a serious impact on the specific features of the seismic energy accumulation and release, since the duration of the postseismic stage can reach $25 \%$ of the total seismic cycle duration [13].

Explanation of the occurrence patterns of the largest catastrophic earthquakes with source lengths reaching $1000 \mathrm{~km}$ along the strike can be obtained within the framework of a number of mechanical models employing the concept of the simultaneous destruction of several neighboring asperities. A simple mechanical model considering the interaction of 
two adjacent asperities was developed by Ruff [43]. The model consisted of two sliders connected to the overhanging plate and to each other by elastic springs under conditions of friction on contact zone. The author concluded that the presented rather simple deterministic model of roughness interaction provides a satisfactory explanation of the complex regularities of the large earthquakes' occurrence in subduction zones. In [44], a more complex model was presented, consisting of a pair of asperities causing mechanical coupling of interacting plates. In this case, the asperities were separated by an aseismically slipping segment of the subduction interface, which prevented the simultaneous destruction of the asperities, and, consequently, the formation of a lengthy seismic rupture. This paper mainly investigated the probability of rupture propagation through the slipping segment, depending on its geometric dimensions and rheological parameters. In one of the most recent works [45], a systematization of previous studies was carried out in order to study the process of interaction and simultaneous destruction of two separated asperities causing interplate coupling. For this purpose, long earthquake sequences (up to 500 events) were modeled in the aforementioned study assuming constant friction and elastic moduli of the medium, but variable relative positions of asperities both along and across the strike plane of a potential seismic rupture.

The combination of seismic displacement regions with aseismic slip regions, usually observed along subduction interfaces, was explained in [46] based on a fault model and quasi-dynamic asperities with time-varying friction and the possibility of rupture healing depending on the stress level. The obtained results of numerical simulation reproduce the main characteristics of the behavior of a segment of the subduction zone.

Note that both the basic asperity model and later models developing this concept do not consider the non-zero tangential component in the plate convergence velocity. Differences in seismic regimes established in different subduction regions are explained by different degrees of mechanical coupling, as well as different sizes and configurations of the asperities. Thus, the generation of catastrophic earthquakes in the southern part of the Chilean subduction zone, in the northern part of the Kuril-Kamchatka subduction zone, and, probably, in the central part of the Aleutian subduction zone is associated, according to the authors of the asperity model, with a very strong mechanical coupling in the interplate contact zone [42]. It is assumed that the relatively frequent occurrence of the largest earthquakes in these regions is explained by the subsequent rupturing of the adjacent segments of the subduction zone with nearly uniform coupling. At the same time, the studies of the distribution of aftershocks that follow the large-magnitude earthquakes in the Aleutian arc suggest that the fundamental principle of the "asperity" model (the seismically-active rupture always originates in the most strongly interlocked segments of a fault, while weakly coupled segments are ruptured aseismically) may be incorrect, at least in the case of the central part of the Aleutian arc [23] and the central part of the Kuril arc [47]. In addition, within the framework of the asperity model, it is difficult to explain the noticeable variations in the length of the fault zones of events with similar magnitudes in the western part of the Aleutian subduction zone, as well as their relatively short recurrence periods.

\subsection{Tectonic Sliver Model}

The effect of the tangential component of the convergence vector on the dynamics of individual segments of subduction zones is considered in the concept of a tectonic sliver. This concept implies that the lateral pressure from side of subducting oceanic plate leads to the formation of folds and faults in the overhanging edge of the continental plate, oriented both sub-parallel and sub-perpendicular to the subduction axis $[5,48,49]$. Presumably, the main factor controlling the emergence of these structures is mechanical coupling in the zone of interplate contact. However, the researchers declare opposite opinions regarding the specific characteristics of this parameter. In particular, in [50,51], it was suggested that faults at the edge of the plate are formed under conditions of weakened mechanical contact. In other studies, the cause for the segmentation of island arcs and active continental margins, 
on the contrary, is attributed to the high coefficient of interplate coupling $[48,49,52,53]$. One way or another, as a result of non-orthogonal subduction, the margin of the overhanging plate is separated, and a so-called tectonic sliver is formed. Tectonic slivers are bounded by a deep-sea trench on the outer side, while on the inner side they are limited by an active strike-slip fault, subparallel to the island arc and located at the edge of the continental plate at a distance of 100-300 km from the trench. Tectonic slivers are found in about $50 \%$ of the present-day subduction zones [52]. Under the tangential force produced by subducting plate, the sliver moves along the island arc, which is confirmed by the existence of subvertical strike-slip faults in the back-arc basin [54]. Thus, the fault separating the sliver from the oceanic plate accommodates most of the normal component of plate convergence, while most of the shear component of motion is encompassed by the fault at the boundary between the sliver and the continental plate [55].

In the Komandor segment of the Aleutian subduction zone, the domains of shallow seismicity of the same intensity are found on both sides of the island arc [8]. This suggests the presence of a tectonic sliver in this segment of the subduction zone. Moreover, the focal mechanisms represent thrust-strike-slip faults at the boundary between the oceanic plate and the sliver and normal-strike-slip faults at the boundary between the sliver and the continental plate. In 2017, an M7.7 earthquake with a strike-slip mechanism occurred in the Komandor segment of the Aleutian arc, probably marking the boundary between the sliver and the continental plate.

According to [7], transverse faults were identified in the Komandor segment, seen as canyons in the bottom topography. These faults break the Komandor seismic gap into eight blocks $50-100 \mathrm{~km}$ in size. Thus, the Komandor segment of the Aleutian subduction zone can be structurally represented as either a single narrow lithospheric block, a sliver, or as an ensemble of smaller blocks. Note also that the tectonic sliver model is inapplicable to explain the occurrence of extremely large earthquake fault zones east of $168^{\circ} \mathrm{W}$.

\subsection{Keyboard Model of Earthquake Generation under Oblique Subduction Settings}

In this study, in order to explain the shortening of the seismic cycle in the western part of the Aleutian island arc, we applied the keyboard model for the generation of megathrust earthquakes in subduction zones $[11,56,57]$. According to this model, the frontal part of the island arc is divided into wedge-shaped blocks (keys), separated from each other by faults nearly perpendicular to the island arc and extending in depth down to the subduction interface. From the outside, these blocks are bounded by a deep-sea trench, and on the inside, by a system of longitudinal faults separating them from the rear region of the island arc. The frontal island-arc blocks are coupled to the subducting slab through a viscous contact layer consisting of a mixture of sedimentary rocks with basalt breccias $[58,59]$. During the interaction of oceanic and continental lithospheric plates, the blocks accumulate stresses, which are released during the megathrust earthquakes [11].

The formation of discontinuities in the margin of the overhanging lithospheric plate is explained by the nonuniform subduction of the oceanic plate under the continental one, which is caused by the inhomogeneous distribution of the coupling coefficient along the interplate surface $[6,10]$. Positive landforms of the subducting plate, such as seamounts, fault ledges, bedrock outcrops, etc. are regions of higher friction coefficient than adjacent regions covered by oceanic sediments. Thus, tensile and shear strength in the regions with a high friction is reached later compared with the regions of lower friction, which, apparently, is the cause of segmentation. Note that the conditions sufficient for dividing the medium into quasi-independent blocks are universal and can take place in both normal and oblique subduction. The difference is that under conditions of normal subduction, the segmentation of an island arc or an active continental margin mainly reflects the structure of the top surface of subducting oceanic plate. In case of oblique subduction, the structural formations of the ocean floor, determining the segmentation of the continental margin, are being displaced along the deep-sea trench axis. Such a displacement is well traced in the structures of the Aleutian island arc west of $177^{\circ} \mathrm{W}$. Here, most of the faults transverse to 
the arc intersecting the island-arc margin do not coincide with the continuation of faults dividing the oceanic plate into segments.

The probable existence of faults, having transverse direction relative to the island arcs, is supported by the focal mechanism solutions, as well as the geomorphological data obtained during the joint oceanographic surveys [60].

In response to external loading of varying intensity, duration, and frequency, the resulting ensemble of blocks and faults (Figure 3) can exhibit the behavior of a consolidated or an unconsolidated medium. This is due to the fact that the block-separating faults have significantly lower effective strengths in comparison with the material of the blocks. This leads to the possibility of noticeable relative displacements of the blocks under loading. Thus, at different stages of the seismic cycle, the lithosphere consisting of quasi-independent blocks can deform both as a single structure and as a set of separate structural elements due to the ability of the blocks to move independently. During the most prolonged stage of the seismic cycle (interseismic stage), the active margin separated by faults behaves like a continuous medium reacting to external pressure caused by the subducting plate. In contrary, during the shortest seismic stage of the cycle, the same active margin appears to follow the motion pattern of an unconsolidated medium, since the earthquake source involves only one or several neighboring blocks.

The length of the resulting fault zone, and, consequently, the number of displaced blocks is mainly determined by the magnitude of the accumulated stresses and the friction force at the lateral surfaces of the interacting segments. During the postseismic stage of the cycle, relaxation of residual elastic stresses occurs due to quasi-independent displacements of blocks. This behavior of the blockwise structure is clearly identified from the analysis of seismotectonic deformations associated with the largest earthquakes of the early $21 \mathrm{st}$ century [61-63].

The study [11] provided a description of the model of the megathrust earthquakes generation for the case of orthogonal subduction (Figure 3a). Below we consider the effect of the tangential component of the convergence rate on the process of elastic stress accumulation. In case of oblique subduction, the keyboard blocks are compressed against each other due to the action of the longitudinal component of the adhesion force at the blocks' bottom surfaces, arising as a result of the non-orthogonal motion of the subducting plate (Figure 3b). Since the displacement of blocks in the longitudinal direction is limited by the geometry of the subduction zone, rather large shear stresses emerge in the contact layer. These stresses are proportional to effective viscosity of the layer, and can be treated as background or "initial" stresses. With respect to these "initial" stresses in the contact layer, additional stresses develop, corresponding to the stages of block loading and unloading in the orthogonal direction relative to the arc during the seismic cycle. In the presence of a significantly large "initial" stress in the contact layer, the time required for loading of the compressible block until the megathrust earthquake occurs, should be significantly shorter under oblique subduction setting compared with the preparation time of the equal event in the orthogonal subduction setting.

Therefore, the recurrence period of the largest earthquakes in the same arc segments under oblique subduction becomes much shorter in comparison with the orthogonal case. In the western part of the Aleutian subduction zone, the tangential component of the plate convergence vector is quite prominent, and the convergence velocity magnitude increases in the east-west direction. Thus, the accumulation of stresses sufficient for the occurrence of a megathrust earthquake in the western segment of the island arc will occur much faster than in the case of orthogonal subduction. Another characteristic feature of the seismic process occurring under oblique subduction setting is associated with the emergence of ultra-long fault zones, as, for example, during the 1957 Aleutian earthquake or the 2004 Sumatra earthquake. Such abnormally long fault zones arise due to the aforementioned longitudinal compression of the blocks, leading to a domino effect (chain reaction) due to the sufficiently large adhesion force between frontal blocks, which causes a keyboard block shifted towards the ocean during a large earthquake to drag the neighboring blocks in the 
same direction. In the above reasoning, we do not consider the westernmost part of the Aleutian island arc (Komandor Islands segment) where subduction almost disappears and conditions of almost pure dextral shear are formed. The proposed keyboard model is not suitable for such a tectonic setting.

(a)

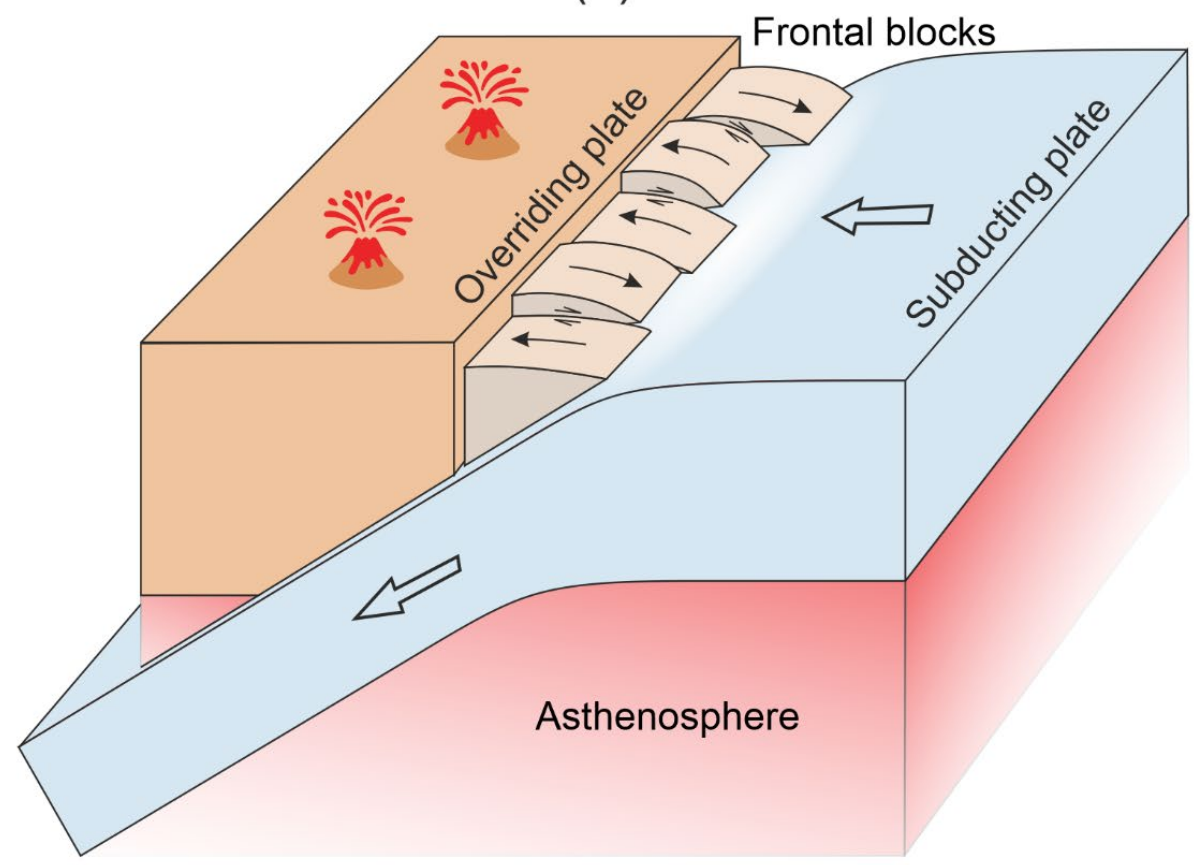

(b)

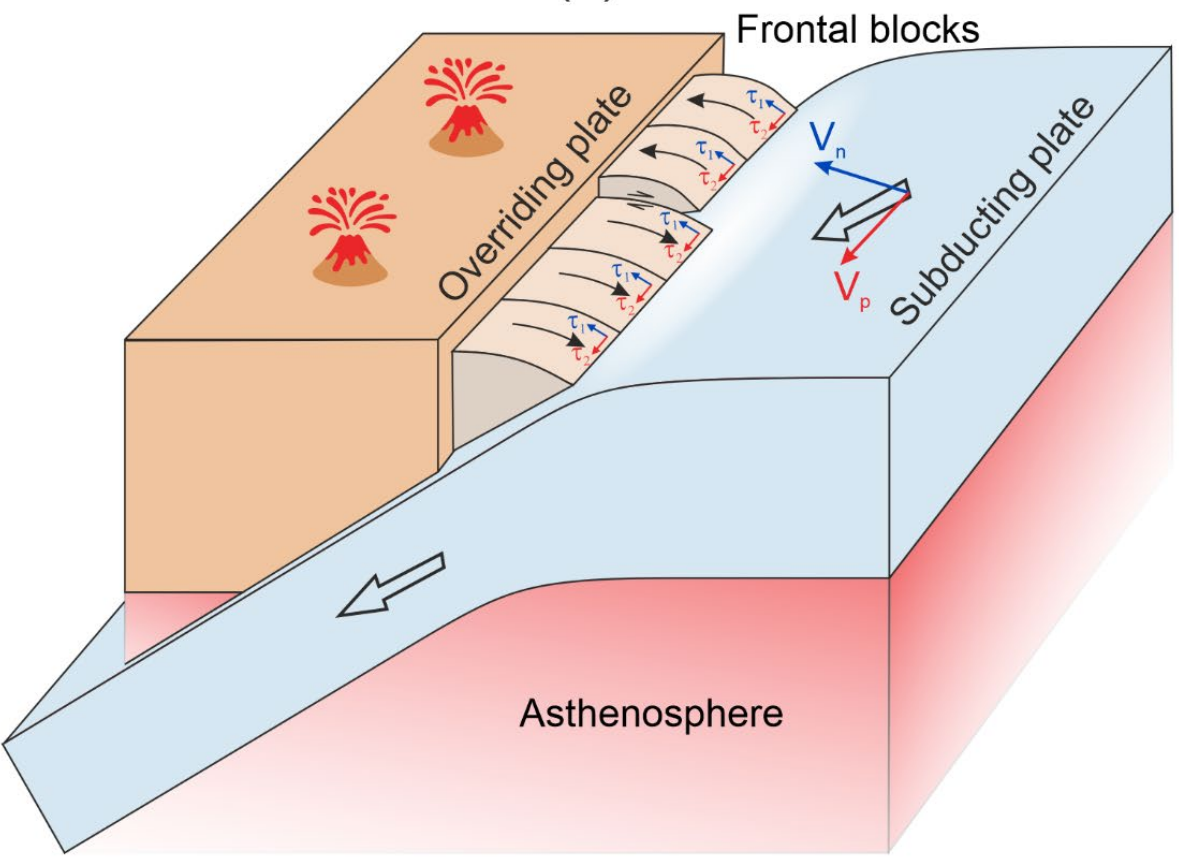

Figure 3. Sketch of the keyboard model featuring the motion of the blockwise structure in the frontal part of the island arc under normal (a) and oblique (b) subduction. Vn-arc normal rate of motion of subducting plate; $\mathrm{Vp}$ - arc parallel rate of motion of subducting plate; $\tau 1$-shear stresses at the bottom of seismogenic blocks caused by orthogonal subduction of the oceanic plate; $\tau 2$-initial shear stresses at the bottom of seismogenic blocks caused by their longitudinal compression. 
Another prominent feature of seismic cycles in the western part of the Aleutian subduction zone is the absence of recurring events of similar magnitudes and the length of fault zones inside the same segment. Within the framework of the keyboard model, the boundaries of the fault zones of events repeated inside one segment of the subduction zone do not have to be exactly repeated. The fault zone of a new megathrust earthquake may involve neighboring blocks that have not shifted during the previous event. At the same time, some blocks that had been displaced during the previous seismic cycle may remain unaffected due to the fact that the stresses accumulated in them are insufficient for dynamic slip.

\section{Discussion}

The tectonic setting features of subduction zones, formed due to the presence of a pronounced tangential component of the plate convergence vector, can significantly affect the preparation of the largest subduction earthquakes, reducing the duration of the seismic cycle. The keyboard model of the generation of the megathrust earthquakes allowed us to explain the peculiarities of the seismic process in subduction regions revealed by the seismology and satellite geodetic data. At the same time, the generation of megathrust earthquakes is a complex process and, in general, it is necessary one should take into account the influence of the whole variety of contributing factors when studying seismic cycles. Several attempts have been performed to identify the fundamental characteristics of seismic regimes in different subduction zones. In [64], numerical modeling of the blockwise structure dynamics was carried out in order to study the dependence of seismicity intensity on the average subduction slab angle in the seismogenic zone and the direction of the plate convergence vector. In particular, it was found that the most intense seismic activity was observed when the average slab angle fell between $40^{\circ}$ and $50^{\circ}$, while seismic activity was substantially lower for angles of about $30^{\circ}$ or $60^{\circ}-70^{\circ}$. In addition, an overall increase in seismic activity is expected when the plate convergence angle was close to $40^{\circ}$ [64]. However, as the authors noted, a more detailed analysis of the seismicity of various subduction zones is required in order to confirm the established regularities. The Aleutian subduction zone is characterized by an average angle of dip of the Wadati-Benioff zone varying from $8^{\circ}$ to $19^{\circ}$ [65] and a plate-convergence angle varying from $0^{\circ}$ (normal subduction) to near $90^{\circ}$ (dextral shear) (Figure 1b).

An additional factor affecting the seismic cycle in subduction regions is the stability of deformation and slip along the faults, which can significantly depend on the frictional properties of rocks. To date, our ideas about the influence of the frictional properties of rocks on the stability of deformation processes are mostly based on the results of experimental studies of various modes of sliding blocks along the interface under conditions of limited velocities. However, the features of the regional mineralogical and petrochemical composition, hydrological setting, and geological structure can differ significantly from the average characteristics of materials used in laboratory experiments, which might lead to a much more complicated distributions of frictional properties.

The results of a number of international projects focused on earthquake-associated faults drilling have shown that the frictional properties of rocks extracted from different faults differ significantly [66]. This may be the reason behind totally different modes of deformation and sliding in the fault zones under the similar stress-strain state conditions. As a result, the seismic process pattern can change from one zone to another: from the predominance of "quiet" earthquakes [67] to the dominance of moderate-magnitude events [68] and the occurrence of mega-earthquakes with $M \geq 9$ [69], similar to the 1960 Great Chilean or 2011 Tohoku events.

One of the crucial factors affecting the frictional properties of rocks, as is known from laboratory experiments, is temperature [70]. The steady-state temperature regime of the upper part of subduction zone depends on the temperature distribution in the slab, plate convergence rate, dip angle of the Benioff zone, and thermal properties of rocks composing the lithosphere of interacting plates and the underlying asthenosphere [71]. In [72], mean temperature estimates for the world's major subduction zones had been obtained, which 
then were correlated with historical seismicity. Calculations have shown that subduction zones in which strongest earthquakes originate, including those with $M \geq 9$ (in particular, the Sumatra-Andaman, Chilean, and Alaska segments of the Aleutian subduction zone), are characterized by a similar thermal state.

The Aleutian subduction zone is also characterized by extreme heterogeneity in the heat flux distribution. Thus, there is evidence of a higher degree of heating in the central part of the Aleutian zone. In particular, data were obtained on the adakite volcanism manifestation, associated with oceanic crust melting in the arc segment near Adak Island [73,74]. As noted by [75], adakites formation means that the age of the oceanic plate near the subduction zone should be less than $25 \mathrm{Ma}$. The age of the subducting Pacific plate in the central part of the Aleutian subduction zone is $~ 52 \mathrm{Ma}$, which means that an additional source of heat is required for adakite volcanism to develop in this area. Additional heating of the upper part of the subduction zone may occur due to the presence of shear stresses exceeding $100 \mathrm{MPa}$ in subduction zones with a pronounced tangential component [76]. An increase in temperature leads to a change in the mechanical parameters of rocks, including a local decrease in the effective viscosity.

As shown by laboratory experiments [77], the mode of shear deformation of the fault radically changes from stable mutual slip to intermittent slip with a decrease in the viscosity of thin fluid films lubricating the surfaces of the material particles filling the main fault. Thus, it is likely that the reduced effective viscosity of the contact layer between the islandarc wedge and the subducting plate surface in the central part of the Aleutian subduction zone under conditions of increased heat flux can cause an abrupt change in the stable sliding mode to dynamic rupturing, which, in turn, determines the specific features of the earthquake preparation process.

Finally, nonuniform temporal behavior of the seismic regime should be taken into account when interpreting the data on strong earthquakes' recurrence in the western part of the Aleutian subduction zone. That is, the high seismic activity in the Aleutian subduction zone observed in the middle of the XX century may represent only a shortterm intensification and not reflect the stationary trends in the development of the seismic process in the region.

\section{Conclusions}

Our analysis showed that the orientation of the plate convergence vector relative to subduction zone axis can have a significant impact on the generation of the megathrust earthquakes in subduction zones. In particular, revealing the features of the seismogenic process in the western part of the Aleutian subduction zone allowed us to found that the seismic cycles in the western part of the Aleutian arc are, on average, shorter than in the eastern one. In addition, it was revealed that the megathrust earthquakes, repeating in the same areas of the western part of the Aleutian subduction zone differ both in magnitude and length of fault zones. As a mechanism explaining the reduction in the seismic cycles' duration and noticeable differences in the spatial extent and localization of the fault zones of events with similar magnitudes occurring in the same segment of the western half of the Aleutian subduction zone, a keyboard model of the megathrust earthquakes generation in oblique subduction setting is proposed. To figure out the specific contribution of the proposed mechanism to the observed features of the seismic process in oblique subduction regions, a further study is planned involving the creation of numerical model that considers the regional rheological structure and tectonic setting.

Author Contributions: Conceptualization, L.I.L. and I.S.V.; methodology, L.I.L. and I.S.V.; software, Y.V.G. and D.A.A.; validation, Y.V.G. and D.A.A.; resources, Y.V.G. and I.S.V.; writing-original draft preparation, I.S.V., Y.V.G. and D.A.A.; writing-review and editing, I.S.V., Y.V.G., D.A.A. and L.I.L.; visualization I.S.V. and D.A.A.; supervision, L.I.L.; project administration, D.A.A.; funding acquisition, L.I.L. All authors have read and agreed to the published version of the manuscript.

Funding: This study was funded by the Russian Science Foundation, grant number 20-17-00140. 


\section{Institutional Review Board Statement: Not applicable.}

Informed Consent Statement: Not applicable.

Acknowledgments: We appreciate reviewers' attention, comments, and advice aimed at improving this study.

Conflicts of Interest: The authors declare no conflict of interest.

\section{References}

1. Kanamori, H.; Brodsky, E.E. The physics of earthquakes. Rep. Prog. Phys. 2004, 67, 429-1496. [CrossRef]

2. Hwang, L.J; Kanamori, H. Of the May 7, 1986 Andreanof Islands earthquake source parameters. Geophys. Res. Lett. 1986, 13, 1426-1429. [CrossRef]

3. Nishenko, S.P.; Jacob, K.H. Seismic potential of the Queen Charlotte-Alaska-Aleutian seismic zone. J. Geophys. Res. 1990, 95, 2511-2532. [CrossRef]

4. Ekström, G.; Engdahl, E.R. Earthquake source parameters and stress distribution in the Adak Island region of the central Aleutian Islands, Alaska. J. Geophys. Res. 1989, 94, 15499-15519. [CrossRef]

5. McCaffrey, R. Oblique plate convergence, slip vectors, and forearc deformation. J. Geophys. Res. 1992, 97, 8905-8915. [CrossRef]

6. Avdeiko, G.P.; Palueva, A.A. The Kamchatka subduction zone: Seismotectonic regionalization and geodynamics. J. Volcanolog. Seismol. 2011, 5, 3-18. [CrossRef]

7. Lobkovsky, L.I.; Baranov, B.V.; Dozorova, K.A.; Mazova, R.K.; Kiselman, B.A.; Baranova, N.A. The Komandor seismic gap: Earthquake prediction and tsunami computation. Oceanology 2014, 54, 519-531. [CrossRef]

8. Baranov, B.V.; Monin, A.S. On the Kuril-Aleutian subduction. Dokl. Akad. Nauk SSSR 1985, 281, 1328-1331. (In Russian)

9. Andô, M. Source mechanisms and tectonic significance of historical earthquakes along the Nankai trough, Japan. Tectonophysics 1975, 27, 119-140. [CrossRef]

10. Cormier, V.F. Tectonics near the junction of the Aleutian and Kuril-Kamchatka Arcs and a mechanism for Middle Tertiary magmatism in the Kamchatka Basin. Geol. Soc. Am. Bull. 1975, 86, 443-453. [CrossRef]

11. Lobkovsky, L.I.; Kerchman, V.I.; Baranov, B.V.; Pristavakina, E.I. Analysis of seismotectonic processes in subduction zones from the standpoint of a keyboard model of great earthquakes. Tectonophysics 1991, 199, 211-236. [CrossRef]

12. Spence, W. The Aleutian Arc: Tectonic blocks, episodic subduction, strain diffusion, and magma generation. J. Geophys. Res. 1977, 82, 213-230. [CrossRef]

13. Fedotov, S.A. The Seismic Cycle, Possibility of the Quantitative Seismic Zoning, and Long-Term Seismic Forecasting. In Seismic Zoning in the USSR; (In Russian). Medvedev, S.V., Ed.; Nauka: Moscow, Russia, 1968; pp. 133-166.

14. Beck, S.; Barrientos, S.; Kausel, E.; Reyes, M. Source characteristics of historic earthquakes along the central Chile subduction zone. J. S. Am. Earth Sci. 1998, 11, 115-129. [CrossRef]

15. Freymueller, J.T.; Woodard, H.; Cohen, S.C.; Cross, R.; Elliott, J.; Larsen, C.F.; Hreinsdottir, S.; Zweck, C. Active Deformation Process in Alaska, Based on 15 Years of GPS Measurements. In Geophysical Monograph Series; Wiley: Hoboken, NJ, USA, 2008; Volume 179, pp. 1-42.

16. Minster, J.B.; Jordan, T.H. Present-day plate motions. J. Geophys. Res. 1978, 83, 5331-5354. [CrossRef]

17. DeMets, C.; Gordon, R.G.; Argus, D.F.; Stein, S. Effects of recent revisions to the geomagnetic reversal time scale on estimates of current plate motions. Geophys. Res. Lett. 1994, 21, 2191-2194. [CrossRef]

18. Wesson, R.L.; Boyd, O.S.; Mueller, C.S.; Bufe, C.G.; Frankel, A.D.; Petersen, M.D. Revision of Time-Independent Probabilistic Seismic Hazard Maps for Alaska: U.S. Geological Survey Open-File Report 2007-1043; U.S. Geological Survey: Reston, VA, USA, 2007 ; p. 33.

19. Porto, N.M.; Fitzenz, D.D. An Alternative Segmentation Model for the Alaskan Aleutian Megathrust. Bull. Seismol. Soc. Am. 2016, 106, 1125-1132. [CrossRef]

20. Nicolsky, D.J.; Freymueller, J.T.; Witter, R.C.; Suleimani, E.N.; Koehler, R.D. Evidence for shallow megathrust slip across the Unalaska seismic gap during the great 1957 Andreanof Islands earthquake, eastern Aleutian Islands, Alaska. Geophys. Res. Lett. 2016, 43, 10,328-10,337. [CrossRef]

21. Witter, R.C.; Carver, G.A.; Briggs, R.W.; Gelfenbaum, G.; Koehler, R.D.; la Selle, S.P.; Bender, A.M.; Engelhart, S.E.; Hemphill-Haley, E.; Hill, T.D. Unusually large tsunamis frequent a currently creeping part of the Aleutian megathrust. Geophys. Res. Lett. 2016, 43, 76-84. [CrossRef]

22. Davison, F.C.; Scholz, C.H. Frequency-moment distribution of earthquakes in the Aleutian Arc: A test of the characteristic earthquake model. Bull. Seismol. Soc. Am. 1985, 75, 1349-1361. [CrossRef]

23. Boyd, M.; Lerner-Lam, A.L. Spatial distribution of turn-of-the-century seismicity along the Alaska-Aleutian arc. Bull. Seismol. Soc. Am. 1988, 78, 636-650.

24. Fedotov, S.A. Long-term Earthquake Prediction for the Kuril-Kamchatka Arc; Moscow: Nauka, Russia, 2005; p. 34. (In Russian)

25. International Seismological Centre. ISC-GEM Earthquake Catalogue. 2022. Available online: http://www.isc.ac.uk/iscgem/ (accessed on 12 January 2022).

26. Ruppert, N.; Lees, J.; Kozyreva, N. Seismicity, Earthquakes and Structure Along the Alaska-Aleutian and Kamchatka-Kurile Subduction Zones: A Review. Geophys. Monogr. 2013, 172, 129-144. 
27. Minsch, J.H.; Stover, C.W.; Dunbar, P.K.; Baldwin, F.W. Earthquakes in the United States, January-March 1981; Series 871-A; U.S. Geological Survey Circular: Denver, CO, USA, 1982; p. 16.

28. USGS Earthquake Catalog. Available online: https:/ / earthquake.usgs.gov/earthquakes/search/ (accessed on 12 January 2022)

29. Johnson, J.M.; Tanioka, Y.; Ruff, L.J.; Satake, K.; Kanamori, H.; Sykes, L.R. The 1957 great Aleutian earthquake. Pure Appl. Geophys. 1994, 142, 3-28. [CrossRef]

30. Balakina, L.M.; Moskvina, A. Characterization of the seismogenic process in the Aleutian island arc: I. Source relations of the large earthquakes of 1957, 1986, and 1996 in the Andreanof Islands. Izv. Phys. Solid Earth 2008, 44, 631-659. [CrossRef]

31. Lopez, A.M.; Okal, E.A. A seismological reassessment of the source of the 1946 Aleutian 'tsunami' earthquake. Geophys. J. Int. 2006, 165, 835-849. [CrossRef]

32. Liu, C.; Lay, T.; Xiong, X. The 29 July 2021 MW 8.2 Chignik, Alaska Peninsula Earthquake Rupture Inferred from Seismic and Geodetic Observations: Re-rupture of the Western 2/3 of the 1938 Rupture Zone. Geophys. Res. Lett. 2022, 49, e2021GL096004. [CrossRef]

33. Gates, O.; Gibson, W. Interpretation of the configuration of the Aleutian Ridge. Bull. Geol. Soc. Amer. 1956, 67, 127-146. [CrossRef]

34. Geist, E.L.; Childs, J.R.; Scholl, D.W. The origin of summit basins of the Aleutian Ridge: Implications for block rotation of an arc massif. Tectonics 1988, 7, 327-341. [CrossRef]

35. Ryan, H.F.; Scholl, D.W. Geologic implications of great interpolate earthquakes along the Aleutian arc. J. Geophys. Res. 1993, 98, 22135-22146. [CrossRef]

36. Vikulin, A.V. A variant of the long-term seismic forecast for Kamchatka Bay and Kronotskii Peninsula. J. Vulkanol. Seismol. 1986, 3, 72-83.

37. Sykes, L.R.; Kisslinger, J.B.; House, H.; Davies, J.N.; Jacob, K.H. Rupture zones of great earthquakes in the Alaska-Aleutian arc, 1784 to 1980. Science 1980, 210, 1343-1345. [CrossRef] [PubMed]

38. Benz, H.M.; Tarr, A.C.; Hayes, G.P.; Villaseñor, A.; Furlong, K.P.; Dart, R.L.; Rhea, S. Seismicity of the Earth 1900-2010 Aleutian Arc and Vicinity; Series 2010-1083-B; USGS-United States Geological Survey: USA: Reston VA, USA, 2011.

39. Davies, J.N.; Sykes, L.; House, L.; Jacob, K. Shumagin seismic gap, Alaska: History of great earthquakes, tectonic setting and evidence for high seismic potential. J. Geophys. Res. 1981, 86, 3821-3855. [CrossRef]

40. Liu, C.; Lay, T.; Xiong, X.; Wen, Y. Rupture of the 2020 MW 7.8 earthquake in the Shumagin gap inferred from seismic and geodetic observations. Geophys. Res.Lett. 2020, 47, e2020GL090806. [CrossRef]

41. Lallemant, H.G.A.; Oldow, J.S. Active displacement partitioning and arc-parallel extension of the Aleutian volcanic arc based on Global Positioning System geodesy and kinematic analysis. Geology 2000, 28, 739-742. [CrossRef]

42. Lay, T.; Kanamori, H. An Asperity Model of Large Earthquake Sequences in Earthquake Prediction: An International Review; AGU: Washington DC, WA, USA, 1981; pp. 579-592.

43. Ruff, L.J. Asperity distributions and large earthquake occurrence in subduction zones. Tectonophysics 1992, 211, 61-83. [CrossRef]

44. Kaneko, Y.; Avouac, J.P.; Lapusta, N. Towards inferring earthquake patterns from 513 geodetic observations of interseismic coupling. Nat. Geosci. 2010, 3, 363-369. [CrossRef]

45. Rosenau, M.; Horenko, I.; Corbi, F.; Rudolf, M.; Kornhuber, R.; Oncken, O. Synchronization of great subduction megathrust earthquakes: Insights from scale model analysis. J. Geophys. Res. Solid Earth 2019, 124, 3646-3661. [CrossRef]

46. Senatorski, P. Effect of slip-weakening distance on seismic-aseismic slip patterns. Pure Appl. Geophys. 2019, 176, 3975-3992. [CrossRef]

47. Steblov, G.M.; Grekova, T.A.; Vasilenko, N.F.; Prytkov, A.S.; Frolov, D.I. Dynamics of the Kuril-Kamchatka subduction zone from GPS. Izv. Phys. Solid Earth 2010, 46, 440-445. [CrossRef]

48. Fitch, T.J. Plate convergence, transcurrent faults, and internal deformation adjacent to Southeast Asia and western Pacific. J. Geophys. Res. 1972, 23, 4432-4460. [CrossRef]

49. Beck, M.E.J. On the mechanism of tectonic transport in zones of oblique subduction. Tectonophysics 1983, 93, 1-11. [CrossRef]

50. Liu, X.; McNally, K.C.; Shen, Z.K. Evidence for a role of the downgoing slab in earthquake slip partitioning at oblique subduction zones. J. Geophys. Res. 1995, 100, 15351-15372. [CrossRef]

51. Yu, G.; Wesnousky, S.G.; Ekstrom, G. Slip partitioning along major convergent plate boundaries. Pure Appl. Geophys. 1993, 140, 183-210. [CrossRef]

52. Jarrard, R.D. Terrain motion by strike-slip faulting of forearc slivers. Geology 1986, 14, 780-783. [CrossRef]

53. Chemenda, A.; Lallemand, S.; Bokun, A. Strain partitioning and interplate friction in oblique subduction zones: Constraints provided by experimental modeling. J. Geophys. Res. 2000, 105, 5567-5581. [CrossRef]

54. Levina, V.I.; Lander, A.V.; Mityushkina, S.V.; Chebrova, A.Y. The Seismicity of the Kamchatka Region: 1962-2011. J. Volcanolog. Seismol. 2013, 7, 37-57. [CrossRef]

55. Kogan, M.G.; Frolov, D.I.; Vasilenko, N.F.; Freymueller, J.T.; Steblov, G.M.; Ekström, G.; Titkov, N.N.; Prytkov, A.S. Plate coupling and strain in the far western Aleutian arc modeled from GPS data. Geophys. Res. Lett. 2017, 44, 3176-3183. [CrossRef]

56. Lobkovsky, L.I.; Vladimirova, I.S.; Alekseev, D.A.; Gabsatarov, Y.V. Two-element keyboard model of strongest subduction earthquakes generation. Dokl. Earth Sci. 2021, 496, 72-75. [CrossRef]

57. Lobkovsky, L.I.; Vladimirova, I.S.; Gabsatarov, Y.V.; Alekseev, D.A. Keyboard Model of Seismic Cycle of Great Earthquakes in Subduction Zones: Simulation Results and Further Generalization. Appl. Sci. 2021, 11, 9350. [CrossRef] 
58. Shreve, R.L.; Cloos, M. Dynamics of sediment subduction, melange formation, and prism accretion. J. Geophys. Res. 1986, 91, 10229-10245. [CrossRef]

59. Sorokhtin, O.G.; Lobkovsky, L.I. Mechanism for pulling of sediments in subduction zone of lithospheric plates. Izv. Phys. Solid Earth 1976, 12, 3-10.

60. Baranov, B.V.; Ivanchenko, A.I.; Dozorova, K.A. The Great 2006 and 2007 Kuril Earthquakes, Forearc Segmentation and Seismic Activity of the Central Kuril Islands Region. Pure Appl. Geophys. 2015, 172, 3509-3535. [CrossRef]

61. Lobkovsky, L.I.; Vladimirova, I.S.; Gabsatarov, Y.V.; Baranov, B.V.; Garagash, I.A.; Steblov, G.M. Seismotectonic deformations related to the 2010 Maule earthquake at different stages of the seismic cycle from satellite geodetic observations. Dokl. Earth Sci. 2017, 477, 1498-1503. [CrossRef]

62. Lobkovsky, L.I.; Vladimirova, I.S.; Gabsatarov, Y.V.; Steblov, G.M. Seismotectonic deformations related to the 2011 Tohoku earthquake at different stages of the seismic cycle, based on satellite geodetic observations. Dokl. Earth Sci. 2018, 481, 1060-1065. [CrossRef]

63. Vladimirova, I.S.; Lobkovsky, L.I.; Gabsatarov, Y.V.; Steblov, G.M.; Vasilenko, N.F.; Prytkov, A.S.; Frolov, D.I. Patterns of the seismic cycle in the Kuril island arc from GPS observations. Pure Appl. Geophys. 2020, 177, 3599-3617. [CrossRef]

64. Solov'ev, A.A.; Rundkvist, D.V. Modeling of seismicity for the arc subduction zone. Dokl. Earth Sci. 1998, 362, $256-260$.

65. Hayes, G.P.; Wald, D.J.; Johnson, R.L. Slab1.0: A three-dimensional model of global subduction zone geometries. J. Geophys. Res. 2012, 117, B01302. [CrossRef]

66. Brodsky, E.E.; Ma, K.F.; Mori, J.; Saffer, D.M.; The participants of the ICDP/SCEC International Workshop. Rapid Response Drilling: Past, Present, and Future. Sci. Drill. 2009, 8, 30. [CrossRef]

67. Saito, T.; Ujiie, K.; Tsutsumi, A.; Kameda, J.; Shibazaki, B. Geological and frictional aspects of very-low-frequency earthquakes in an accretionary prism. Geophys. Res. Lett. 2013, 40, 703-708. [CrossRef]

68. Ikari, M.; Marone, C.; Saffer, D.; Kopf, A.J. Slip weakening as a mechanism for slow earthquakes. Nat. Geosci. 2013, 6, 468-472. [CrossRef]

69. Ujiie, K.; Tanaka, H.; Saito, T.; Tsutsumi, A.; Mori, J.J.; Kameda, J.; Brodsky, E.E.; Chester, F.M.; Eguchi, N.; Toczko, S.; et al. Low coseismic shear stress on the Tohoku-Oki megathrust determined from laboratory experiments. Science 2013, 342, 1211-1214. [CrossRef]

70. Den Hartog, S.A.M.; Spiers, C.J. Influence of subduction zone conditions and gouge composition on frictional slip stability of megathrust fault. Tectonophysics 2013, 600, 75-90. [CrossRef]

71. Molnar, P.; England, P. Temperatures in zones of steady-state underthrusting of young oceanic lithosphere. Earth Planet. Sci. Lett. 1995, 131, 57-70. [CrossRef]

72. McCaffrey, R. Influence of recurrence times and fault zone temperatures on the age-rate dependence of subuction zone seismicity. J. Geophys. Res. 1997, 102, 22839-22854. [CrossRef]

73. Kay, R.W. Aleutian magnesian andesites: Melts from subducted Pacific ocean crust. J. Volc. Geoth. Res. 1978, 4, 117-132. [CrossRef]

74. Yogodzinski, G.M.; Kelemen, P.B. Slab melting in the Aleutians: Implications of an ion probe study of clinopyroxene in primitive adakite and basalt. Earth Planet. Sci. Let. 1998, 158, 53-65. [CrossRef]

75. Avdeiko, G.P.; Palueva, A.A.; Kuvikas, O.V. Adakites in subduction zones of the Circum Pacific: An overview and analysis of geodynamic settings. Vestn. KRAUNTs. Nauk. Zemle 2011, 17, 45-60. (In Russian)

76. Peacock, S.M.; Rushmer, T.; Thompson, A.B. Partial melting of subducting oceanic crust. Earth Planet. Sci. Lett. 1994, 121, 227-244. [CrossRef]

77. Kocharyan, G.G.; Ostapchuk, A.A. The influence of viscosity of thin fluid films on the frictional interaction mechanism of rock blocks. Dokl. Earth Sci. 2015, 463, 757-759. [CrossRef] 